\title{
THE ELECTROENCEPHALOGRAM IN HEPATO-LENTICULAR DEGENERATION (WILSON'S DISEASE) ${ }^{1}$
}

\author{
Grant L. Heller, M.D. ${ }^{2}$ and Kenneth A. Kooi, M.D. \\ The Department of Neurology and the Neuropsychiatric Institute, University o: Michigan, \\ Ann Arbor, Mich. (U.S.A.)
}

(Received for publication: October 19, 1961)

(Resubmitted: February 16, 1962)

Most textbooks of neurology and of electroencephalography offer little or no information about the EEG in hepato-lenticular degeneration (HLD). This fact is not surprising, because HLD is an uncommon disease and so the opportunity to study a group of patients is limited. However, a search of the available world literature reveals 29 studies reporting 80 cases in which EEG interpretations are available. This report attempts to evaluate these cases as a group and to relate the findings in an additional five cases to trends evident from the prior studies. EEG's were abnormal in 43, questionably normal in six and normal in 31 cases (see Table I). A patient with more than one EEG has been tabulated as "abnormal" if at least one tracing was abnormal, even though he may also have had one or more normal records.

The types of abnormalities reported varied; the most common were continuous generalized slow activity, bursts of slow waves, and asymmetries. Focal abnormalities have also been noted. Hollister et al. (1960) reported a patient with seizures, presumed to be unrelated to previous shock therapy; the main feature of the EEG was a left frontal slow wave focus. Although there had been no definite clinical sign corresponding to this focus, at post mortem examination the left frontal subcortical white matter showed spongy softening. No other such definite EEG-pathological correlation was found.

1 Aided by a grant B-2560 from the National Institute of Neurological Diseases and Blindness, United States Public Health Service.

2 Present address: Mount Sinai Hospital, Cleveland 6, Ohio (U.S.A.).
Konovalov et al. (1957) cited 28 cases; three were described in detail, two more were illustrated, and the rest noted as "normal" or "abnormal". These authors stated that paroxysmal EEG's occur frequently in HLD with or without clinical epilepsy; they reported one case with clinical seizures and spike-and-wave patterns on the EEG. Zhirmunskaya and Chukhrova (1959) also commented upon the occurrence of paroxysmal "sharp and slow waves" without clinical convulsive disorder.

EEG findings during dimercaprol (BAL) therapy have been reported. Streifler and Feldman (1953) presented a patsent with a slow, paroxysmal EEG before treatment; this patient showed parallel clinical and EEG improvement during therapy. Multiple clinical and EEG examinations were done. Giordano (1956) reported a patient whose initial EEG was questionably abnormal and whose tracings showed minimal changes toward normal on BAL therapy.

No correlations could be extablished statistically by $t$-test between EEG abnormality and either the age at onset of the disease or the duration of the disease from data in the literature (Table I). A trend toward greater EEG abnormality with more severe clinical involvement appeared to exist. There was a possible tendency toward relationship between EEG abnormality and degree of tremor and incoordination. No other clinical factor (mental state, motor power, tone, sensor changes, etc.) seemed to correlate with EEG findings.

Our present series consists of nine EEG's done on seven different patients (Table II). The first EEG of patient R.P. was also reported by Scharenberg and Drew (1954) and patient

Electroenceph. clin. Neurophysiol., 1962, 14: 520-526 
A. M. was reported also by Bihl (1959). Every patient had Kayser-Fleischer rings. There were three definitely abnormal (A) records, three borderline (B), and three normal $(\mathrm{N})$ tracings. In all cases, even in those with normal records, the basic frequency was abnormally slow or at the slow end of the normal spectrum (see Fig. 1). this minor change was caused by penicillamine therapy.

A.M. had a normal record in 1955 , reported by Bihl in 1959; a tracing done in 1960 showed some minimal borderline changes. She also had several courses of therapy (usually BAL; penicillamine once briefly) between the two EEG's.

Inspection of Table II indicates that no close

A

B

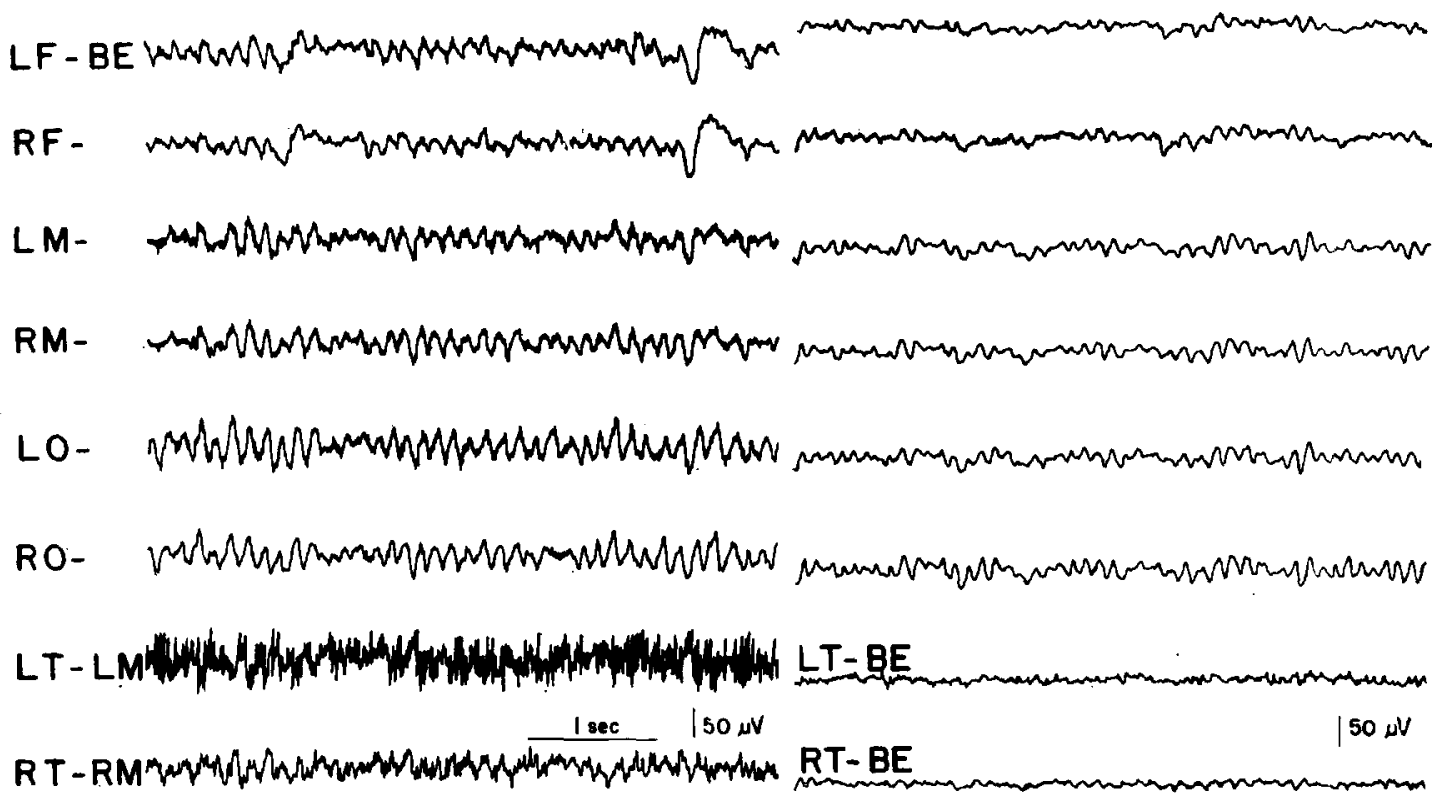

Fig. 1

R.P., male, age 20. $A$ : tracing obtained 5/17/51. Duration of illness 2 years. Basic pattern slightly slow $(7.5-8 \mathrm{c} / \mathrm{sec})$. $B$ : recorded $1 / 19 / 53$. Three courses of BAL followed first EECr. EEG appears improved with faster basic frequency and lower amplitude. Questionable inprovement in neurological status.

Other trends included occasional sharp diphasic forms bicentrally, continuous slow activity (usually $4-8 \mathrm{c} / \mathrm{sec}$, occasionally slower), and bursts. As in other reports, no abnormality specific for this disease was found.

Two patients had two EEG's each. R. P. showed slight background improvement in his second tracing, about $11 / 2$ years after the first (Fig. 1); whether this change was due to the three courses of BAL therapy he received or to spontaneous remission is open to speculation. B.M. had an increase of $1 \mathrm{c} / \mathrm{sec}$ in background frequency in his second record compared with the first; it is impossible to state whether or not relationship existed between clinical and EEG abnormality. Age at onset and duration of illness did not seem to be correlated with EEG abnormality; one of the patients with an abnormal record had only a 7 month history of illness. Degree of tremor and incoordination roughly parallelled the degree of EEG abnormality; however, in one case, rigidity and bradykinesia of severe degree were present in the face of a normal EEG (W.O., Table II); the literature seems to agree with this point. It should be pointed out in this regard that the effect of therapy complicates the evaluation of liver disease.

Electroenceph. clin. Neurophysiol., 1962, 14: 520-526 


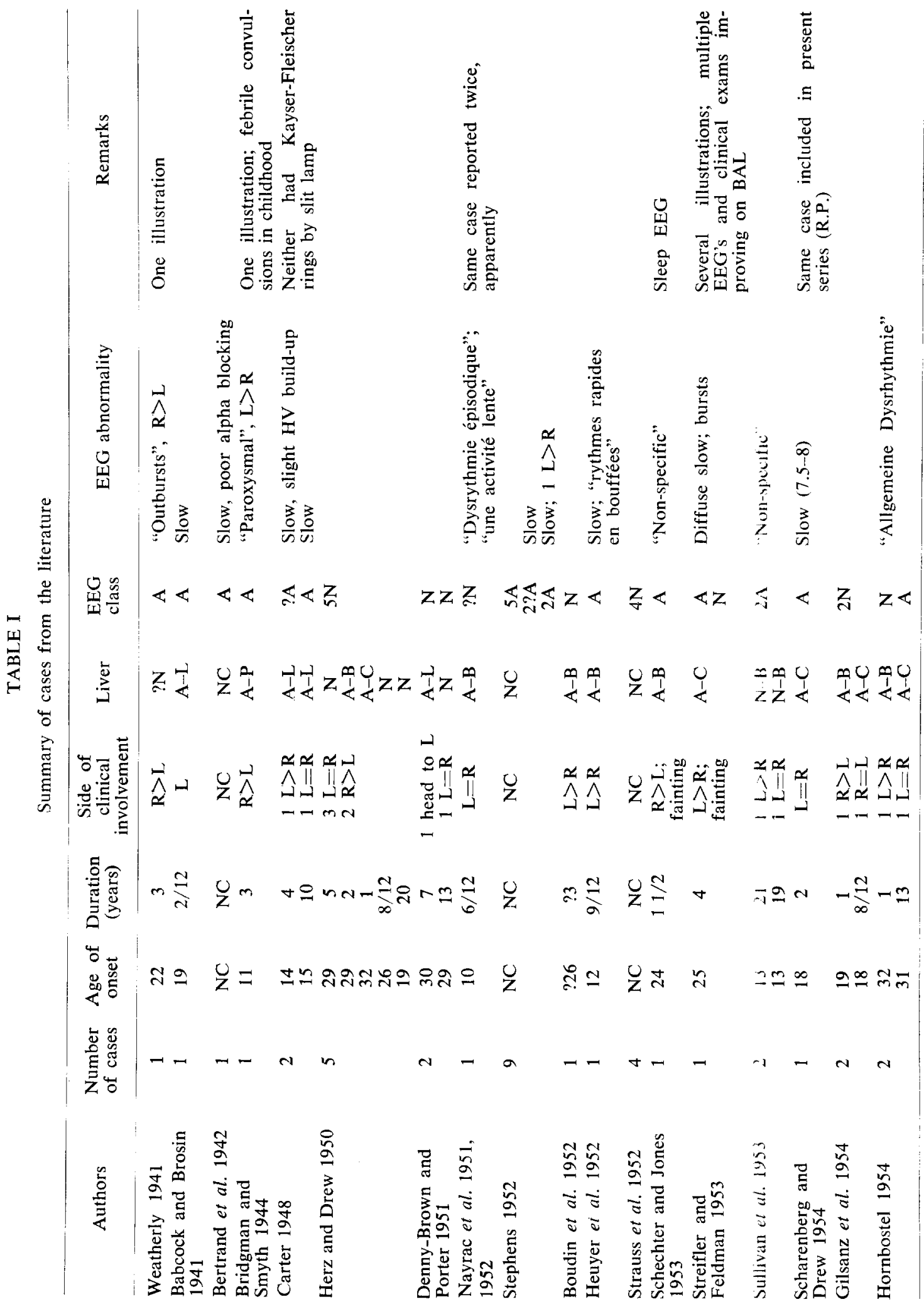



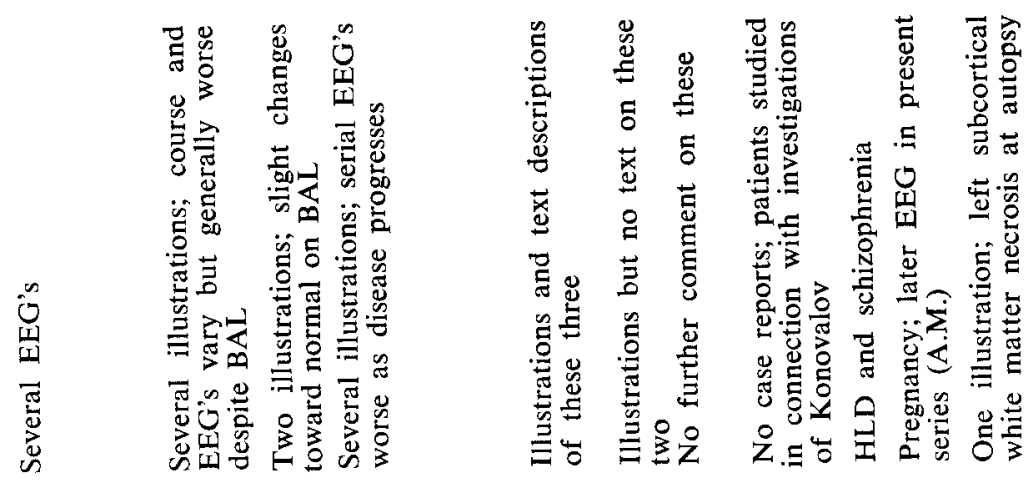

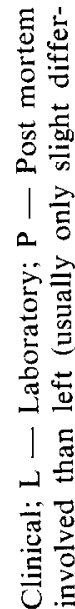
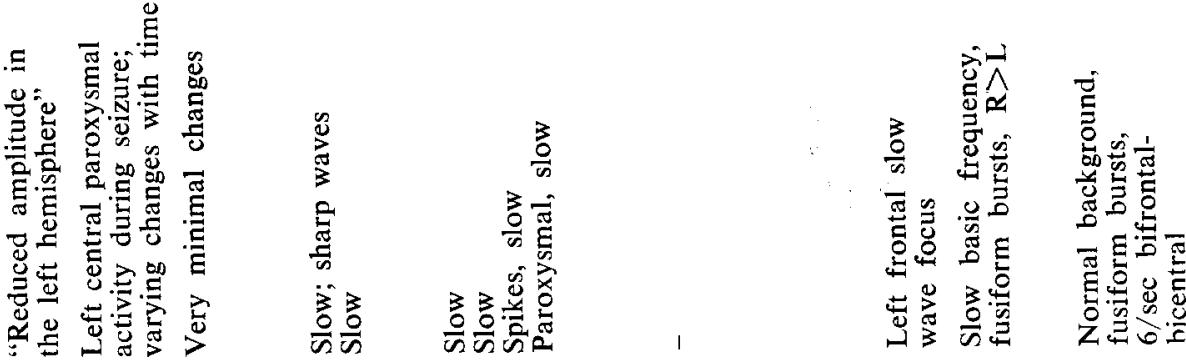

し

苍冬

$\geqq 8$

胥串

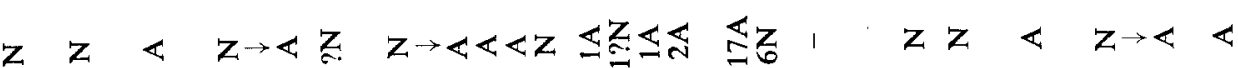

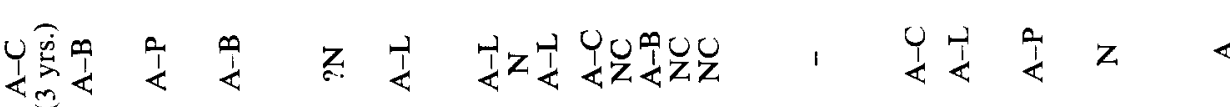

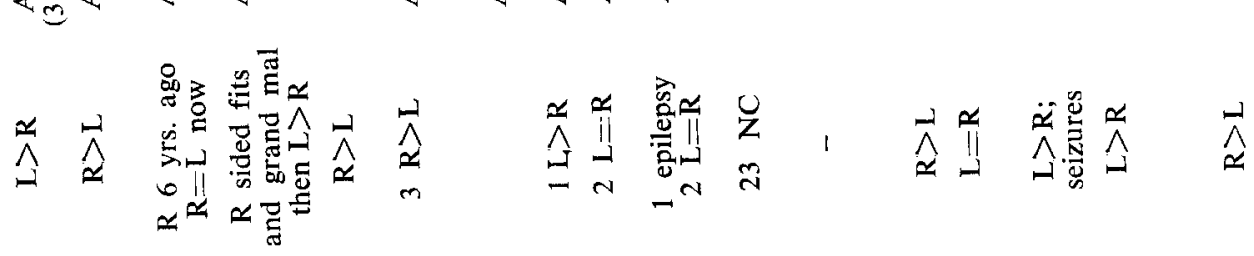

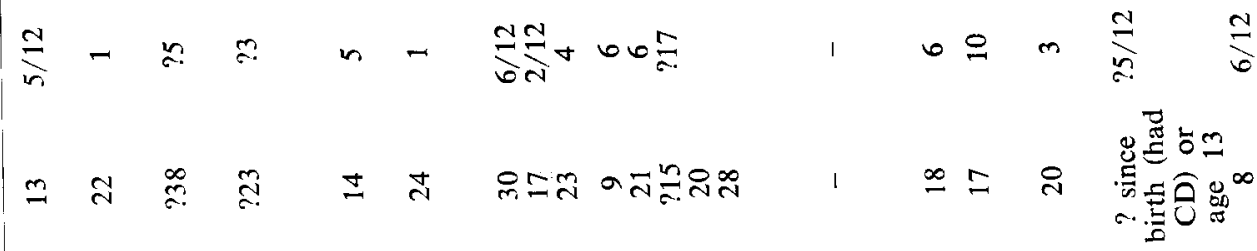




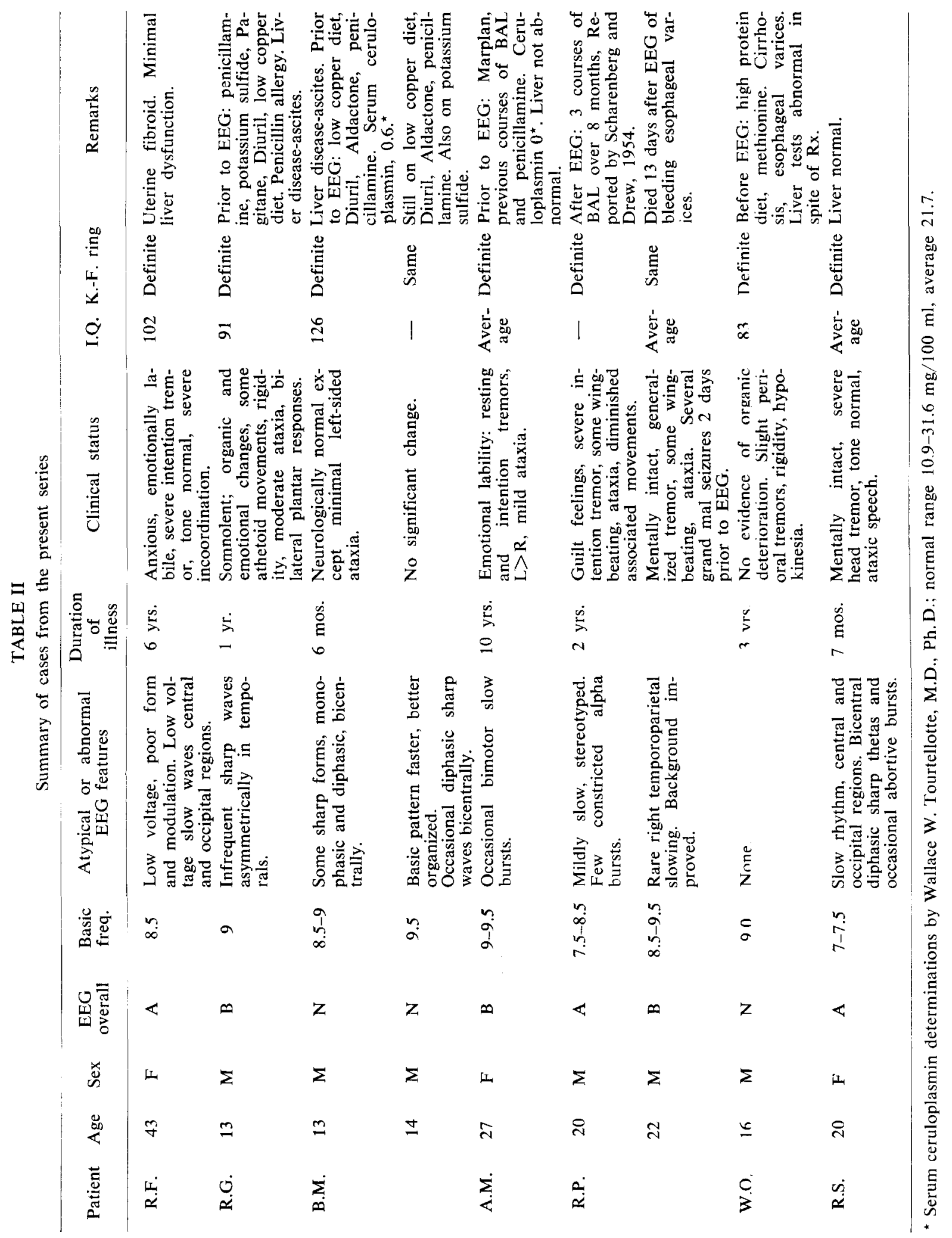


It is interesting that all our patients except one (W.O.) had "average" or higher I.Q. ratings. I.Q. did not appear to correlate with the EEG. It is impossible to state whether the mental retardation of W.O. was life-long or secondary to HLD.

Extremely low serum ceruloplasmin values occurred without significant EEG abnormality (B.M. and A.M., Table II). At the present time we cannot make any attempt at neurochemicalEEG correlations in HLD.

\section{SUMMARY}

The literature on EEG's in hepato-lenticular degeneration has been reviewed; over half of 80 reported patients had abnormal tracings. Eight additional EEG's on seven patients are presented; two definitely abnormal, three borderline and three normal. Trends include continuous slowing of background frequency and sharp diphasic forms bicentrally and elsewhere. There is no specific EEG abnormality in this disease.

Although there are many exceptions, in general the degree of EEG abnormality parallels the severity of clinical involvement. No individual clinical finding consistently relates to EEG abnormality, although there is a suggestion both from our cases and those previously reported that tremor and incoordination may show such a relationship.

Some patients have EEG improvement during or after treatment; it is uncertain whether this change is cause-and-effect or coincidence. More studies of pre- and post-treatment EEG's would be of interest.

\section{REFERENCES}

Alajolanine, T., Bertrand, I., Boudin, G. et Pépin, B. Etude anatomoclinique, biologique et chimique d'un cas de pseudo-sclérose de Westphal-Strumpell. Rev. neurol., 1955, 93: 701-729.

BABCOCK, G. G. and Brosin, H. W. Hepatolenticular degeneration: Report of a case. Arch. Neurol. Psy. chiat. (Chicago), 1941, 46: 431-439.

BEARD, A. W. The association of hepatolenticular degeneration with schizophrenia. A review of the literature and case report. Acta psychiat. (Kbh.), 1959, 34: 411-428.

Berard-Badier, M., Löwenthal, A., Bernard, R., Payan, H. el Gastaut, H. Dégénérescence hépatolenticulaire. Étude anatomo-clinique, électroen- céphalographique et biochimique à propos de trois cas dont deux jumeaux. Psychiat. et Neurol. (Basel), 1960, 140: 445-475.

Bertrand, I., Lacape, R. et Godet, J. Caractères de l'électro-encéphalogramme au cours de la pseudosclérose de Westphal. C.R. Soc. Biol. (Paris), 1942, 136: 427-428.

Binl, J. H. The effect of pregnancy on hepato-lenticular degeneration (Wilson's disease): Report of a case. Amer. J. Obstet. Gynec., 1959, 78: 1182 1188.

Boudin, G. Pepin, B. et Calatchi. Cas familial de dégénérescence hépatolenticulaire. Troubles du métabolisme des acides aminés et du cuivre. Effets du traitement par le B.A.L. Rev. neurol., 1952, 87: 271-293.

Bridgman, O. and Smyth, F. S. Progressive lenticular degeneration. J. nerv. ment. Dis., 1944, 99: 534 543.

Carter, H. R. Hepatolenticular degeneration: A report of four cases in a Spanish-American family with differential diagnosis and treatment. J. nerv. ment. Dis., 1948, 107: 150-159.

Denny-Brown, D. and Porter, H. The effect of BAL (2,3-dimercaptopropanol) on hepatolenticular degeneration (Wilson's disease). New Engl. J. Med., 1951, 245: 917-925.

Faure, J. et Loiseau, P. L'électroencéphalogramme dans la maladie de Wilson-Westphal-Strumpell. Encéphale, 1957, 46: 108-128.

Gilsanz, V., Segovia, J. M., Castro-Menduza, H. J. y Goytre, A. Degeneración hepatolenticular. Rev. clin. esp., 1954, 54: 212-225.

Grordano, G. B. Sulla degenerazione epatolenticolare. Contributo clinico. Riv. Neurobiol, 1956, 2: 6197.

Herz, E. and Drew Jr., A. L. Hepatolenticular degeneration: Analysis of dyskinetic phenomena; Relation of degree of hepatic damage to course of disease; Nervous disorders in ordinary disease of the liver. Arch. Neurol. Psychiat. (Chicciso), 1950, 63: 843 -874.

Heuyer, G., Lebovici, Kodja et Delle. Mouvements anormaux par maladie de Wilson chez l'enfant. Rev. neurol., 1952, 86: 704-705.

Hollister, L. E., Cull, V. L., Gonda, V. A. and Kolb, F. O. Hepatolenticular degeneration: Clinical, biochemical and pathologic study of a patient with fulminant course aggravated by treatment with BAL and Versenate. Amer. J. Med., 1960, 28: $623-630$

Hornbostel, H. Neuere Erkenntnisse über das hepatolentikuläre Syndrom. Schweiz. med. Wschr., 1954, 84: 7-11.

Konovalov, N. V., Zhirmunskaya, E. A. and Chukhrova, V. A. Electricheskaia aktivnost' mozga pri gepato-lentikuliarnoi degeneratisii. $Z$. Nevropat. i Psihiat., 1957, 57: 584-590.

Lamy, M., Nick, J., Jammet, M. L., Aussannaire, M. et Grasset, A. Maladie de Wilson: Apparition des signes neurologiques trois ans après l'installation

Electroenceph. clin. Neurophysiol., 1962, 14: 520-526 
d'une cirrhose hypersplénomégalique. Rev. neurol., 1955, 93: 568-570.

Larmande, A. M. et Margaillan, A. Syndrome de Westphal-Strumpell et anneau de Kayser-Fleischer. Algérie méd., 1955, 59: 345-347.

Lichtenstein, B. W. and Gore, I. Wilson's disease - chronic form: Clinical-pathological observations in a brother and sister. A. M. A. Arch. Neurol. Psychiat., 1955, 73: 13-21.

Nayrac, P., Houcke, E., Biserte, G. et Rabache, R. Dégénérescence hépatolenticulaire chez la soeur et le frère. Ponction-biopsie du foie. Aminoacidurie. Rev, neurol., 1951, 85: 388-392.

Nayrac, P., Houcke, E., Biserte, G. et Rabache, R. Idées actuelles sur la dégénérescence hépato-lenticulaire (à propos d'un double cas familial). Écho méd. Nord, 1952, 23: 98-109.

Scharenberg, K. and Drew Jr., A. L. The histopathology of Wilson's disease: A study with silver carbonate. J. Neuropath. exp. Neurol., 1954, 13: 181-190.

Schechter, M. M. and Jones, C. A. Hepatolenticular degeneration: Review of the literature and report of a case with dimercaprol (BAL) therapy. A. $M$.
A. Arch. intern. Med., 1953, 91: 541-549.

Stephens, J. W. The EEG in hepato-lenticular degeneration. Electroenceph. clin. Neurophysiol.. 1952, 4: 110.

Strauss, H., Ostow, M. and Greenstein, L. Diagnostic electroencephalography. Grune and Stratton, New York, 1952: 88.

Streifler, M. and Feldman, S. Eifect of dimercaprol (BAL) in hepatolenticular degeneration: Report of a case, with clinical and electroencephalographic study. Arch. Neurol. Psychic:. (Chicago), 1953, 69: 84-90.

Sullivan, F. L., Martin, H. L. and McDowell, F. Wilson's disease (hepatolenticular diseases): A family study. Arch. Neurol. I'sychiat. (Chicago), 1953, 69: 756-759.

Weatherly, H. Progressive hep.tolenticular degeneration with electro- and pnel moencephalograms: Report of a case. Amer. J. Ru entgenol., 1941, 45: 714-717.

Zhirmunskaya, E. A. and Chu-hrova, V. A. The electric activity of the brain in hepato-lenticular degeneration. Proc. first int. Cong. neurol. Sci., 1957. Pergamon Press, London, 1959, 3: 336-337.

Reference: Heller, G. L. and KoOI, K. A. The electroencephalogram in hepato-lenticular degeneration (Wilson's disease). Electroenceph. clin. Neurophysiol., 1962, 14: 520-526. 